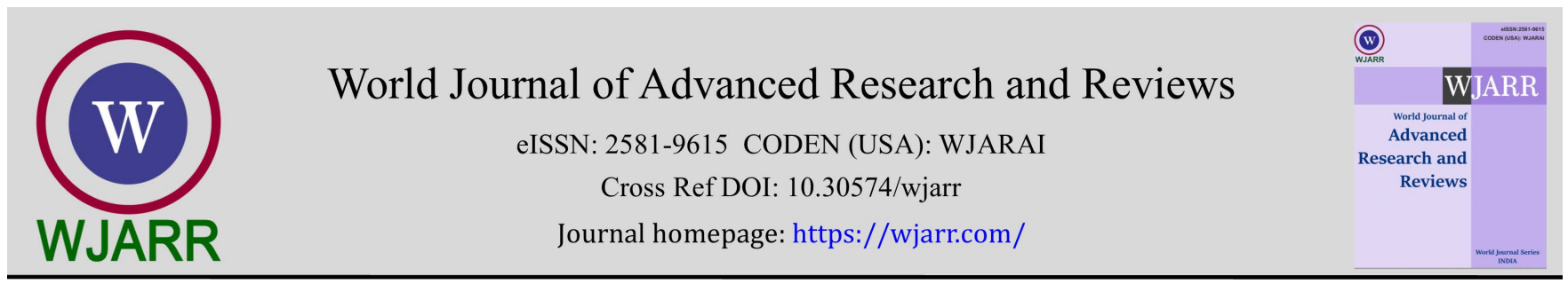

(RESEARCh ARTICLE)

\title{
Effects of processing on the mineral content and proximate composition of Arachis hypogeae (Groundnut) seeds
}

\author{
Nyah Nkereuwem Udo *, Okon Okon Effiong, Ukpong Etiowo George and Effiong James Okon \\ Department of Science Technology Akwa Ibom State Polytechnic, Ikot Osurua, Ikot Ekpene Akwa Ibom State, Nigeria.
}

World Journal of Advanced Research and Reviews, 2021, 12(01), 387-395

Publication history: Received on 11 August 2021; revised on 15 October 2021; accepted on 17 October 2021

Article DOI: https://doi.org/10.30574/wjarr.2021.12.1.0379

\begin{abstract}
Analysis of mineral content and proximate composition of Arachis hypogaea seeds were carried out using standard analytical method (AOAC, 2000). Raw, boiled and fried groundnut (Arachis hypogaea) seeds were analyzed for proximate and mineral composition. The results revealed that the raw, boiled and fried seeds contained $(6.70 \% \pm 0.04$, $5.63 \% \pm 0.04$ and $7.68 \% \pm 0.05$, Ash contents), $(4.10 \% \pm 0.05,3.85 \% \pm 0.03$ and $4.37 \% \pm 0.04$, crude fibre $),(20.38 \% \pm$ $0.30,23.86 \% \pm 0.04$ and $25.64 \% \pm 0.05$, crude protein), (39.32\% $\pm 0.04,32.76 \% \pm 0.01$ and $46.36 \% \pm 0.06$ crude fat), $(29.86 \% \pm 0.07,33.92 \% \pm 0.03$ and $6.93 \% \pm 0.04$ carbohydrate) respectively. There was a significant difference between the nutritional value of the raw and heat processed samples: Boiling decreased crude fibre, ash contents, crude protein and crude fat. While carbohydrate increased with boiling when compared with the raw and fried groundnut. Minerals increased with increasing heat processing temperature. Calcium; Potassium, Magnesium, Sodium, Phosphorus, Copper, Iron and Manganese showed that $(240.56 \pm 0.03,220.94 \pm 0.04$, and $245.85 \pm 0.02-\mathrm{Ca}),(166.25 \pm 0.05,152.03 \pm 0.06$ and $218.08 \pm 0.50-\mathrm{K}),(40.36 \pm 0.02,44.18 \pm 0.02$ and $46.04 \pm 0.04-\mathrm{Mg}),(352.64 \pm 0.04,396.12 \pm 0.03$ and $402.63 \pm 0.03-$ $\mathrm{Na}),(28.10 \pm 0.05,35.25 \pm 0.01$ and $40.57 \pm 0.02-\mathrm{P}),(2.49 \pm 0.02,2.66 \pm 0.04$ and $2.74 \pm 0.05-\mathrm{Cu}),(14.82 \pm 0.05,13.10 \pm$ 0.02 and $25.51 \pm 0.04-\mathrm{Fe}),(4.07 \pm 0.03,3.78 \pm 0.04$, and $3.44 \pm 0.02-\mathrm{Zn})$ and $(3.41 \pm 0.02,3.11 \pm 0.02$ and $4.77 \pm 0.03-\mathrm{Mn})$ respectively with the raw sample having the least value.
\end{abstract}

Keywords: Arachis hypogeae; Macro element; Micro element; Proximate analysis; Protein deficiency; Caloric value

\section{Introduction}

Arachis hypogaea (Groundnut or peanut) is a species in the legume of family (Fabaceae) and the most important legume in Africa. It is an important crop of Brazilian origin, though now cultivated in tropical and temperature climates [1]. Groundnut is a good protein source and has a high lysine content which makes it a good complement for cereal protein which is low in lysine, [2]. The problem of providing adequate protein for an expanding world population is second only to the overall food problem [3].

Peanuts are generally rich in nutrient, providing over 30 essential nutrients and phytonutrients [4]. A new study by a group of Huntsville researchers found out that boiled peanuts bring out up to four times more chemicals that protect against disease than raw, dry or fried nut. Recent research has also found antioxidants that protect cells against the risk of degenerative disease and other chemicals that may provide health benefits [4].

Groundnut has been used in and around the food industry as food in soups, stew, sauces puddings, 'bakery products and in various other ways such as production of solvents and oils, make up, medicines, textiles Materials, peanut butter, mixed nuts [5].

\footnotetext{
${ }^{*}$ Corresponding author: Essien NE and Nyah Nkereuwem Udo

Department of Science Technology Akwa Ibom State Polytechnic, Ikot Osurua, Ikot Ekpene Akwa Ibom State, Nigeria. 
In Nigeria, there are two major local forms in which groundnut seeds are consumed amongst others. It is either by roasting or boiling. Boiled and roasted groundnut are common street side food in south -south Nigeria. Freshly, boiled or fried, groundnut is a good traditional snacking item with its unique taste. However, there is an increased preference for roasted seeds in comparison to boiled groundnut [5].

Groundnut is widely consumed raw, fried and boiled. Fried groundnuts are enjoyed by many people who combine them with bread, 'cucumber, banana, roasted or boiled maize, drinking Garri, boiled rice, inter alia. It has been used as an adulterant for olive oil.

The oil cake or groundnuts cake is a by-product of groundnut oil production. It forms one of the most valuable livestock cakes of commerce product, as it has a higher protein content than any other similar product.

Groundnuts have a lot of health benefits both in whole forms and when been processed into other products, it primarily contains nutrients (Minerals and vitamins) such as thiamin, Vitamin B3 (niacin), vitamin E, copper, phosphorus, biotin, magnesium, manganese, folate etc. It is just essential as the health benefits to .know also the values of nutrients that constitute groundnut, in other word, called peanut. Scientifically, 100 grams of groundnut contains 567 calories, $7 \%$ of water, 25.8 grams of protein, and 16.1 grams of carbohydrate and 4.7grams of sugar. Some other nutrients present in groundnut with their respective values are; fibre $-8.5 \mathrm{~g}$, fat $-49.2 \mathrm{~g}$, saturated fat- $6.28 \mathrm{~g}$, Monounsaturated fat - $24-43 \mathrm{~g}$, Polyunsaturated fat $-15.56 \mathrm{~g}$, Omega3-30g, Omega 6 -15.56g [5].

Groundnuts have a variety of industrial uses. For example, paints varnish, lubricating oil, leather dressing, furniture polish, insecticides and nitrogencerin are made from peanut oil. Also, soap is made from saponified oil and many cosmetics contain peanut oil and its derivative. The protein content of groundnut oil is used in the manufacture of some textile fibers. Its shells are used in the manufacture of plastic, wallboard, abrasives; fuel, cellulose (used in rayon and paper and mucilage glue) [5]. Essential for Heart and Brain Health: Groundnut mainly the oil contains fatty acids which help to increase the high-density lipoprotein in the body known as the "good cholesterol" and this is so because the fatty acid if contains is monounsaturated, thereby improving the general health conditions of the heart and brain. Again, copper which is a dietary mineral if present in groundnut can prevent the body from coronary heart disease as well as thiamine (Vitamin B1) an important micronutrient that helps to protect human health from cardiac failure.

Repair the body tissues: Just like other leguminous crops; groundnut is a very good source of protein which help to repair and build body tissue. It contains a good amount of phosphorus which human body needs to make proteins necessary for maintenance of bodily functions, growth. And repairs of certain tissues and cells.

Lower the Risk of Cancer: Groundnut is one of the food crops that have-antioxidants in the form of Polyphenol and Resveratrol, which helps to protect the body from diseases such as cancer, heart related disease etc., as it boosts the body's immune system by removing chemicals in the body than can cause or worsen, such health conditions.

\section{Material and methods}

\subsection{Sample collection and preparation for analysis}

Arachis hypogaea seeds were bought at Ikot Osurua Market in Ikot Ekpene, Akwa Ibom State and conveyed in a polythene bag to the Akwa Ibom State Polytechnic Chemistry Laboratory. The Arachis hypogaea seeds were divided into three equal parts for each treatment that comprised raw, frying and boiling. The raw sample was sun dried for 7 days, ground to powder form and stored for analysis. The second portion (frying) $2 \mathrm{~g}$ salt in $5 \mathrm{ml}$ of water was sprinkled on the Arachis hypogaea seeds and sun dried for two hours and fried in an open pan using garri (garri was used to avoid sand) at the base until the seeds turned golden brown. Fried Arachis hypogaea seeds were cooled, dehulled, milled and stored in an airtight container for further analysis. The third portion (Boiling) unshelled groundnut seeds were thoroughly washed in cold water until water was clear. Nuts were soaked in clean water for about 30 minutes before cooking. Cooking was done in a pot using 1 liter of water and $2 \mathrm{~g}$ of salt was added and cooked for about 30 minutes while stirred occasionally. Fully cooked groundnut seeds (Arachis hypogaeai seeds) were soft and similar to that of a cooked dry pea or bean in texture. When cooking was terminated, the remaining water was drained to avoid further moisture uptake by the groundnut. Groundnuts were dehulled, dried, milled and stored for further analysis. 


\subsection{Determination of proximate composition}

Proximate analysis of the (Arachis hypogaea) involves the determination of the major food substances that make up food which include moisture content, carbohydrate, ash content, crude protein, crude fat, and crude fibre. These were determined using universally method of A. O. A. C. [6].

\subsubsection{Determination of Moisture Content}

Procedure

- An empty moisture can was washed thoroughly, dried in an oven, cooled in a desiccators and weighed as $\mathrm{W}_{0}$.

- $5 \mathrm{~g}$ of the groundnut was put into the weighing moisture can and reweighed as $\mathrm{W}_{1}$.

- The can and its contents was oven dried at $70-80^{\circ} \mathrm{C}$ until weight was constant

- It was then cooled in a desiccator and the weight of the dried sample plus can take as $\mathrm{W}_{2}$

- From the data obtained, the percentage of moisture was calculated using the formula

$$
\% \text { moisture }=\frac{W_{1}-W_{2}}{W_{1-} W_{0}} \times \frac{100}{1}
$$

Where:

$\mathrm{W}_{0}=$ Initial weight of the empty can

$\mathrm{W}_{1}=$ Weight of can plus sample before drying

$\mathrm{W}_{2}=$ Weight of can plus sample after drying

\subsubsection{Determination of Ash Content}

Procedure

- A clean, dried porcelain crucible was weighed as $\mathrm{W}_{0}$

- $5 \mathrm{~g}$ of finely ground, dry sample was measured into the empty crucible and weighed as $\mathrm{W}_{1}$

- The sample was charred in a muffle furnace at $550^{\circ} \mathrm{C}-600^{\circ} \mathrm{C}$ until a white or light grey ash results

- The crucible and its content was cooled in a desiccator and then reweighed as $\mathrm{W}_{2}$

- From the data obtained, the percentage of ash was calculated using the formula

$$
\% \text { Ash }=\frac{W_{2}-W_{0}}{W_{1-} W_{0}} \times \frac{100}{1} \text { or } \frac{\text { Weight of ash } \times 100}{\text { Weight of original food }}
$$

Where:

$\mathrm{W}_{0}=$ Weight of empty crucible

$\mathrm{W}_{1}=$ Weight of crucible plus sample before drying and ashing

$\mathrm{W}_{2}=$ Weight of crucible plus sample after ashing

\subsubsection{Determination of Crude Fat}

The fat content in plant tissues is generally extracted with petroleum ether using soxhlet extraction method.

Procedure

- Dry $25 \mathrm{ml}$ extraction flask was oven dried at $105-110^{\circ} \mathrm{C}$ for 3 minutes, cooled in a desiccator and the empty flask weighed as $\left(\mathrm{W}_{2}\right)$

- $5 \mathrm{~g}$ of the sample was weighed into an empty thimble $\left(\mathrm{W}_{0}\right)$ and reweighed as $\mathrm{W}_{1}$

- The extraction flask was filled with petroleum ether (boiling point $40-60^{\circ} \mathrm{C}$ ) and the extraction thimble plugged tightly with cotton wool.

- The soxhlet apparatus was assembled and the thimble allowed to reflux for about 5-6 hours

- The thimble was carefully removed and the petroleum ether in the top container was collected for reuse. 
- The extraction flask was removed and placed in a water bath for petroleum ether to evaporate.

- It was then transferred into a desiccator to cooled and reweighed as $\mathrm{W}_{3}$

- From the data obtained percentage crude fat was calculated using the formula

Where:

$$
\% \text { Fat }=\frac{W_{3}-W_{2}}{W_{1-} W_{0}} \times \frac{100}{1} \text { or } \frac{\text { Weight of Fat } \times 100}{\text { Weight of original food }}
$$

$\mathrm{W}_{0}=$ Weight of empty thimble

$\mathrm{W}_{1}=$ Weight of thimble plus ground sample

$\mathrm{W}_{2}=$ Weight of empty extraction flask

$\mathrm{W}_{3}=$ Weight of extraction flask plus fat.

\subsubsection{Determination of Crude Fibre}

Procedure

- $5 \mathrm{~g}$ of ground sample with petroleum ether was defat for an hour

- It was then boiled under reflux for 30 minutes with $200 \mathrm{ml}$ of a solution containing $1.25 \% \mathrm{of}_{2} \mathrm{SO}_{4}$ per $100 \mathrm{ml}$ solution

- The solution was filtered through cotton wool on a fluted funnel

- Thereafter, it was then washed with boiling water until the washings are no longer acidic.

- The residue was transferred to a solution containing $1.25 \mathrm{~g}$ of $\mathrm{NaOH}$ per $100 \mathrm{ml}$

- Then the final residue was filtered and the residue washed with boiling water several times until it is base $(\mathrm{NaOH})$ free.

- The residue was finally washed twice with ethanol and quantitatively transferred into a pre-weighed crucible, oven dried at $105^{\circ} \mathrm{C}(\mathrm{I} 0)$

- It was finally incinerated in a furnace at $550^{\circ} \mathrm{C}$, allowed to stand at this temperature for 2 hours, cooled in a desiccator and weighed (Io loss in weight)

Calculation

$$
\frac{W_{1}-W_{0}}{\text { Weight of Original sample taken }} \times 100
$$

Where

$\mathrm{W}_{0}=$ Weight of empty crucible

$\mathrm{W}_{1}=$ Weight of crucible and its content after incineration (Ash fibre)

$5 g=$ Weight of original sample taken

\subsubsection{Determination of Crude Protein}

Determination of crude protein usually entails the determination of total nitrogen from which the crude protein can then be calculated by multiplying by a factor. Thus the nitrogen in protein has become the basis for the estimation of protein in food.

Procedure

- $\quad 5 \mathrm{~g}$ of sample was accurately weighed into a standard Kjeldahl flask containing $\mathrm{CuSO}_{4}$, some antibumping chips and conc. $\mathrm{HCl}$.

- The digestion flask was placed in a digestion rack and heated gently for one hour to prevent vigorous charring and frothing.

- The flask and its contents were then subjected to vigorous heating for 5 hours until a clear bluish solution was obtained.

- After digestion, the solution was cooled, then quantitatively transferred into a $100 \mathrm{ml}$ standard flask and made up to the mark with distilled water. 
- $10 \mathrm{ml}$ portion of this digest was pipetted into a distillation apparatus and $40 \% \mathrm{NaOH}$ solution added. Also a conical flask containing $20 \mathrm{ml}$ of boric acid indicator was placed under the condenser outlet and the flas $\mathrm{k}$ for about 5- 7 minutes.

- The ammonia $\left(\mathrm{NH}_{3}\right)$ evolved was distilled, into a $100 \mathrm{ml}$ conical flask containing a solution of saturated boric acid and into which 2 drops of the double indicator has been added. The distillation continued until about three times the original volume was obtained.

- The receiving flask was removed and the tip of the condenser rinsed with distilled water. The distillate in the receiving flask was then titrated with standard $\mathrm{HCl}$ solution until a purple-pink endpoint was reached. A blank determination was also performed without the addition of the sample in the digestion flask. From the data obtained percentage nitrogen was calculated using the formula:

$$
\% \text { Nitorgen }=\frac{V_{s}-V_{0} \times \text { Molarity of acid } \times 0.04 \times V_{1}}{W-V_{2}}
$$

Where:

$\mathrm{V}_{\mathrm{s}}=$ Vol. of acid required to titrate sample

$\mathrm{V}_{0}=$ Vol. of acid required to titrate blank

$\mathrm{W}=$ Weight of sample in grams

$V_{1}=$ Vol. of water used for distilling the digest

$V_{2}=$ Vol. of aliquot used for distillation

Thus $\%$ protein $=\mathrm{N} \times 6.25$

Where $6.25=$ conversion factor

\subsubsection{Determination of Carbohydrate}

Carbohydrate content is obtained by calculating having estimated all the other fractions by subtracting the percentage sum of food nutrients (i.e $\%$ crude protein, $\%$ crude fat, $\%$ crude fibre and $\%$ ash) from 100 . Therefore, $\%$ carbohydrate $=100-(\%$ fat $+\%$ ash $+\%$ fibre $+\%$ protein $)$.

\subsubsection{Determination of the minerals elements}

The mineral elements were determined using Atomic Absorption Spectrophotometer with exception of sodium and potassium that were determined with Flame Emission Spectrophotometer and Phosphorus with Colorimeter

\section{Digestion of Sample}

$5 \mathrm{~g}$ of the ground sample was weighed using a weighing balance into a digestion flask and 10ml of hydrochloric acid and $20 \mathrm{ml}$ of nitric acid were introduced into the mixture. The digestion flask containing the mixture was heated gently at a temperature of $130^{\circ} \mathrm{C}$ until the colour turned colourless, indicating that the digestion was completed. The content in the flask was allowed to cool, $30 \mathrm{ml}$ of distilled water was added to the content and shaken very well. It was then filtered with Whatman fitter paper and the solution was made up to $50 \mathrm{ml}$ with distilled water. After that, it was transferred in to a sample bottle and stored for the determination of ( $\mathrm{Ca}, \mathrm{Mg}, \mathrm{Na}, \mathrm{K}, \mathrm{P}, \mathrm{Cu}, \mathrm{Fe}, \mathrm{Zn}$, and $\mathrm{Mn}$ ).

\subsubsection{Determination of Calcium, Magnesium, Copper, Zinc, Iron, and Manganese}

These elements were determined using Atomic Absorption Spectrophotometer (AAS)

Determination of Sodium and Potassium

These were determined using Flame Emission Spectrophotometer (FES)

Determination of Phosphorus

This was determined using colorimeter 


\section{Results}

The results of the mineral elements and the proximate composition analysis of raw, boiled and fried Arachis hypogaea (groundnut) seeds are as shown in the Table A and B

Table 1 Proximate analysis of the raw, boiled and fried seed of Arachis hypogaea (groundnut)

\begin{tabular}{|l|l|l|l|}
\hline \multicolumn{5}{|c|}{ \% Dry Matter } \\
\hline Chemical property & Raw & Boiled & Dried \\
\hline Ash content & $6.70 \pm 0.04$ & $5.63 \pm 0.04$ & $7.68 \pm 0.05$ \\
\hline Crude fibre & $4.10 \pm 0.05$ & $3.85 \pm 0.03$ & $4.37 \pm 0.04$ \\
\hline Crude protein & $20.38 \pm 0.03$ & $23.86 \pm 0.05$ & $25.64 \pm 0.04$ \\
\hline Crude fat & $39.32 \pm 0.04$ & $32.76 \pm 0.01$ & $46.36 \pm 0.06$ \\
\hline Carbohydrate & $29.86 \pm 0.07$ & $33.92 \pm 0.03$ & $6.93 \pm 0.04$ \\
\hline
\end{tabular}

Table 2 Mineral Composition of raw, boiled and dried seeds of Arachis hypogaea (groundnut) (mg/100g dry weight)

\begin{tabular}{|l|l|l|l|}
\hline \multicolumn{4}{|c|}{ Concentration (Mg/100g Dry Weight) } \\
\hline Mineral & Raw & Boiled & Dried \\
\hline Calcium (Ca) & $240.56 \pm 0.03$ & $220.94 \pm 0.04$ & $245.85 \pm 0.02$ \\
\hline Potassium (K) & $166.25 \pm 0.05$ & $152.03 \pm 0.06$ & $218.08 \pm 0.05$ \\
\hline Magnesium (Mg) & $40.36 \pm 0.02$ & $44.18 \pm 0.02$ & $46.04 \pm 0.04$ \\
\hline Sodium (Na) & $352.64 \pm 0.04$ & $396.12 \pm 0.03$ & $402.63 \pm 0.03$ \\
\hline Phosphorus (P) & $28.10 \pm 0.05$ & $35.25 \pm 0.10$ & $40.57 \pm 0.02$ \\
\hline Copper (Cu) & $2.49 \pm 0.02$ & $2.66 \pm 0.04$ & $2.74 \pm 0.05$ \\
\hline Iron (Fe) & $14.82 \pm 0.05$ & $13.10 \pm 0.05$ & $25.51 \pm 0.04$ \\
\hline Zinc (Zn) & $4.07 \pm 0.03$ & $3.78 \pm 0.04$ & $3.44 \pm 0.02$ \\
\hline Manganese (Mn) & $3.41 \pm 0.02$ & $3.11 \pm 0.02$ & $4.77 \pm 0.03$ \\
\hline
\end{tabular}

\section{Discussion}

The result of the proximate composition is as shown in table A. Fried groundnut had the highest crude protein value (25.64) followed by boiled groundnut (23.86) and the lowest value was recorded for raw groundnut (20.38). This agrees with the previous study by Rehman and Salariga [7], who reported that boiled brings about loss of structural components as well as a loss in protein, fat and ash and this also agrees with the findings of Ayoola and Adeyeye [8]. The lower growth protein of the boiled groundnut seed might also be as a result of leaching of soluble components of the protein into cooking water. This is in agreement with the finding of Jimoh et al., [1] in some seeds and Adeparusi [9], who also made similar observations when autoclaving Lima beans (Phaseolus lunatus L.). Crude protein content demonstrates that groundnut is a valuable source of protein providing the nutrition status of humans.

Fat content of both the raw (39.32) and the fried (46.36) were higher than the boiled groundnut seeds. The reduction of fat as a result of boiling is in agreement with the work of Ayoola and Adeyeye [8]. The high crude fat content of fried seeds could be attributed to increased heating temperature which led to the cleavage of more protein lipid or carbohydrate-lipid linkages thereby facilitating the easy absorption of the fat [10]. Therefore consuming fried groundnut seeds will be beneficial to health since the high lipid content is rich in monosaturated fatty acids and not cholesterol. 
Fried groundnut had the highest crude fibre value (4.37\%) followed by raw (4.10\%) and the lowest value was recorded for boiled groundnut. This agree with the previous study by Thed and Philips [11], who reported an increase in soluble dietary fibre of fried soya beans, also highlighted that cooking under pressure promoted the reduction of natural fibre in red and white kidney beans. The apparent increase in the fibre content of fried groundnut seeds could probably be attributed to the fact that when starchy foods are subjected to prolonged heat treatment, more ordered structures of the starch molecules are rendered indigestible. Thus are regarded as dietary fiber [12 - 13]. The rise in fibre content could be due to the. Browning reactions to produce some products which may be analyzed as lignin. Therefore, consuming fried groundnut seeds regularly with high dietary fiber will have beneficial effects in humans by preventing or alleviating malaria, cardiovascular diseases, diabetes, colon cancer etc (14-15].

The ash content was also found to be highest in fried seeds value $(7.68 \%)$ followed by raw $(6.70 \%)$ and the lowest value was recorded in boiled (5.63\%). This also agrees with the previous study by Ayoola and Adeyeye [8], who reported a higher ash content for fried seeds of groundnut.

Total carbohydrate content was observed to be higher in boiled seeds of groundnut (33.92\%), followed by raw (29.86, $\%$ ) then lowest in fried seeds (6.93\%). This was in line with the findings of Ayoola and Adeyeye [8] who reported a higher value of carbohydrate for boiled seeds of. Groundnut than fried seeds. Therefore, consuming boiled groundnut will give more energy than fried groundnuts. The lost in carbohydrate due to roasting may be attributed to the role of sugar precursor in the production of fried groundnut flavor, where it provides a source of carbon for the production of flavor compounds [1].

The result of the mineral composition of groundnut (Arachis hypogaea) seeds are as shown in Table B. The mineral content of raw, boiled and fried groundnut seeds generally processed increasing the mineral content of the seeds. This is in agreement with the study of Ayoola and Adeyeye [8], which stated that fried groundnut was more advantageous in mineral content than the raw. Heating at higher temperature therefore released the minerals. There was a significant difference in all minerals between the raw, boiled and fried groundnut samples. Sodium had the highest mineral content followed by Calcium, Potassium, Magnesium, Phosphorus, Iron, Manganese, Zinc and Copper was the lowest. The values of these minerals were higher in this present study than the values reported by Ayoola and Adeyeye [8].

Sodium (Na) content of groundnut was 352.64 (Raw), 396.12 (Boiled) and 402.63 (Fried). Sodium, which has the highest concentration and a principal cation in the extracellular fluids in human system. It regulates plasma volume and acid base balance involved in the maintenance of osmotic pressure of the body fluids, preserves normal irritability of muscles and cell permeability, activates nerve and muscle function and involves in ATPase, maintenance of membrane potentials transmission of nerve Impulses [16]. The element calcium (Ca) present with a concentration of 240.56 (Raw), 220.94 (boiled) and 245.85 (fried), Calcium is vital for healthy teeth, bone, aids muscle growth and prevent muscle cramps [17]. The element potassium (K) present with a concentration of 166.25 (Raw), 152.03 (boiled). And 218. 08 (fried). Potassium plays a dominant role in supporting the nervous system and natural heart rhythm. It also stabilizes blood pressure and helps in electrochemical transmission and that has been shown to prevent strokes and works with sodium to maintain a proper water balance in the body [18]. The value of magnesium (Mg) obtained was 40.36 (Raw), 44.18 (Boiled) and 46.04 (fried). Magnesium has also been reported to be involved in maintaining the electrical potential in nerves and activation of some enzyme system [1]

Phosphorus (P) with concentrations of 28.10 (Raw), 35.35 (Boiled) and 40.57 (Fried). It is used in the maintenance of healthy bones and teeth, energy metabolism and acid base balance in the body [17]. The Iron (Fe) content in the sample was 14.82 (Raw), 13.10 (Boiled) and 25.51 (Fried). Iron performs functions of vital importance in the body. Iron is found in the blood being part of the heamoglobin, which is responsible for the colour, and allows the transportation of oxygen from the heart to all the cells. It is essential for the oxidation of carbohydrates, proteins and fats [19]. The element manganese present with concentration of 3.41 (Raw), 3.11 (Boiled) and 4.77 (Fried). Manganese is cofactor of hydrolase, decarboxylase and transferase enzymes [16]. The values of Zinc (Zn) obtained were 4.07 (Raw), 3.78 (Boiled) and 3.44 (Fried). Zinc is a very useful medicinal trace element in human body. It provides a natural protective mechanism against virus specifically those causing respiratory tract infections [19]. It is used extensively in the war against HIV and is believed to have a way in which it delays the integration of the HIV virus in the blood [1].

Copper $(\mathrm{Cu})$ present with a concern fraction of 2.49 (Raw), 2.66 (Boiled) and 2.74 (Fried). Copper is an essential micronutrient necessary for the haematologic and nuerologic system [4]. It is necessary for the growth and formation of bones, formation of myelin sheaths in the nervous systems, and helps in the incorporation of iron in haemoglobin $[16,19]$. The high levels and availability of these minerals in groundnut is a good indication that groundnut consumption will aid in bone formation, blood clotting, and muscle contraction and in certain enzymes in metabolic processes [8]. 


\section{Conclusion}

Groundnut (Arachis hypogaea) seeds are excellent and affordable source of nutrient to the human body such as proteins, carbohydrate, lipids, vitamins minerals and fibre. Groundnuts are often referred to as poor man's protein but, when taken in adequate amounts in any form, will supplement rich nutrients to the body that can provide growth and energy and play a vital role in the prevention of diseases. Metal ions which are cofactors for many enzymes, vitamins that are not synthesized in the body, and monosaturated fatty acids, whose consumption can increase the levels of HDL cholesterol which is good for the heart are present in groundnuts. Essential amino acids that are not synthesized in the body, but are essential as building blocks of proteins and carbohydrate which are the principal sources of energy in the body, can be provided by peanuts. A diet including peanuts could provide all these vital nutrients and play a critical role in preventing diseases and promoting good health.

\section{Compliance with ethical standards}

\section{Acknowledgments}

We acknowledge the contributions of the technologist in the department of Science Technology, Akwa Ibom State polytechnic.

\section{Disclosure of conflict of interest}

The authors declare that this is no conflict of interest.

\section{References}

[1] Jimoh WA, Fagbenro OA, Adeparusi EO. Effect of processing on some minerals, anti-nutrients and nutritional composition of sesame (sesamum indium) seed meals. Electronic Journal of Environmental, Agricultural and Food Chemistry. 2011; 10(1): 32, 1858-1864.

[2] Okaka JC. Handing, storage and processing of plant foods. Journal of Food, Agriculture, Nutrition and Development. 2005; 8: 210-215.

[3] Promeranz Y, Meloan CE. Food analysis: Theory and practical. $2^{\text {nd }}$ edition. Van Nostr and Reinhold, New York, USA. 2002; 581-765.

[4] United State department of Agriculture. Nutrition facts for peanuts, all types of and raw, United State Department of Agricultural (USDA) National Nutrient Database, Retrieved 15 January 2015.

[5] Onyenuga VA. Nigeria's food and feeding stuffs their chemistry and nutritive value. $3^{\text {rd }}$ edition, Ibadan University Press. 2000; 614-622.

[6] AOAC. Official methods of analysis, $15^{\text {th }}$ edition. Association of Official analytical Chemists, Washington D. C. 2000.

[7] Rehman Z, Salariya A. The effect of hydrothermal processing on Anti-nutrients, protein and starch digestibility of food legumes. Int. J. food science Nutr. 2005; 30: 695-700.

[8] Ayoola PB, Adeyeye A. Effect of heating on the chemical composition and physic-chemical properties of Arachis hypogaea (groundnut) seed flour and oil. Pakistan Journal of Nutrition. 2010; 9(8): 751-754.

[9] Adepparus EO. Effect of processing on the nutrients and anti-nutrients of lime bean (Phaseolus Lunatus L.) flour Nahrung/food. 2001; 45(2): 94-96.

[10] Esenusan 0, Ikenebomeh P. Processing effect on the Nutritional and Anti-nutritional content of African Locust bean (Parkia Biglobasi Benth) seed. Pak. Journal Nutr. 2008; 7: 214-219.

[11] Thed ST, Philips RD. Changes of Dietary fiber and starch composition of processed potato products during domestic cooking chemistry. 1995; 52: 301-304.

[12] Chang MC, Morris WC. Effects of Heat treatment on chemical Analysis of Dietary fiber. Journal food Sci. 1990; 55: 1647-1650.

[13] Vidal-Vahvorde A, Frias J. Legume's processing effects on dietary fiber components. J. food Sci. 1991; 56(5): 13501352. 
[14] Dukehart MR, Dulta SK, Vaeth J. Dietary fiber supplementation. Effect on Exocrine pancreatic secretion in man. Am. J. Clin. Nuttr. 1999; 50: 1023-1028.

[15] Cummings JH, Hill MJ, Jenkins DJA, Pearson JR, Wigging HS. Changes in faecal composition and colonic function due to cereal fiber. Am. I. Clin, Nutr. 1996; 29: 1468-1473.

[16] Murray RK, Grammer DK, Mayes PA, Rodwell VW. Harper's biochemistry, (25 th ed.) McGraw-Hill, Health professions divisions, USA. 2000; 17(2): 108-114.

[17] George D. Encyclopedia of foods and their healing power: review and herald publishing Maryland USA. 2004; 1 : 4-12.

[18] Jannifer K. The vital importance of mineral for our health. Innovative Food Science and Emerging Technology. 2009; 21: 310-318.

[19] Malhotra UK. Biochemistry for degree students. Tenth Edition. Yaypee Brothers medical publishers (p) Ltd. New Delhi India. 2000 